\title{
Soil moisture retention on slopes under different agricultural land uses in hilly regions of Southern Transdanubia
}

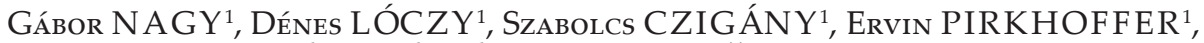 \\ Szabolcs Ákos F ÁBIÁN ${ }^{1}$, Roк CIGLIČ ${ }^{2}$ and Mateja FERK ${ }^{2}$
}

\begin{abstract}
Increasingly severe weather extremes are predicted as one of the consequences of climate change. According to climatic models, weather extremities induce higher risks for both flood and drought in the Carpathian Basin. Throughout the $19^{\text {th }}$ and $20^{\text {th }}$ centuries, flood control relied on cost-intensive engineering structures, but recently ecological solutions have come to the fore. Flood hazard on major rivers could be mitigated if multiple and cumulative water retention opportunities are exploited on the upper sections of tributary catchments. Appropriate land use and landscape pattern changes can shift the infiltration to run-off ratio to the benefit of the former. In the Transdanubian Hills of Southwest Hungary three study areas with different agricultural land use types had been selected and investigated for the impact of landscape micro-features on soil moisture retention capacity with the purpose of conserving water from wet periods for the times of drought. Marked differences in moisture dynamics have been detected between arable land, grasslands and orchards. This fact underlines the need for integrated soil and water conservation. Drought risk was found to be the highest on ploughland. Favourable soil water budgets have been observed in the fields as a function of land use: less intensive types, like grazing land and orchards (particularly tree rows), were identified as places of high water retention capacity. Although serious water stress conditions were also reached in the orchard, it markedly mitigated drought conditions compared to the ploughland.
\end{abstract}

Keywords: water retention, water stress, soil moisture dynamics, ecosystem services, land use, landscape micro-features, Pannonian Basin

Received February 2020; Accepted June 2020.

\section{Introduction}

The reports of the Intergovernmental Panel on Climate Change (IPCC) unequivocally predict growing spatial and temporal concentrations of precipitation for the $21^{\text {st }}$ century (IPCC 2013). This trend is manifested in different manners regionally, but for the Carpathian Basin it involves an increase in flood hazard (Didovets, I. et al. 2019), particularly in flash flood hazard (FÁBIÁN, Sz.Á. et al. 2006; CZIGÁNY,
Sz. et al. 2010; Lóczy, D. et al. 2012). Flash floods are disastrous rapid run-off events, which can be generated in any season by the joint effect of numerous local environmental factors and primarily affect small mountainous or hilly catchments of agricultural utilization, where they cause damage comparable to that of large river floods.

Seldom so concentrated in space and more difficult to localize, droughts are apparently less dangerous than floods (World Bank 2019).

\footnotetext{
${ }^{1}$ Institute of Geography and Earth Sciences, University of Pécs, H-7624 Pécs, Ifjúság útja 6. Hungary. E-mails: gnagy@gamma.ttk.pte.hu, loczyd@gamma.ttk.pte.hu, sczigany@gamma.ttk.pte.hu, pirkhoff@gamma. ttk.pte.hu, smafu@gamma.ttk.pte.hu

${ }^{2}$ Research Centre of the Slovenian Academy of Sciences and Arts, Anton Melik Geographical Institute, Gosposka u. 13. 1000 Ljubljana, Slovenia. E-mails: rok.ciglic@zrc-sazu.si, mateja.ferk@zrc-sazu.si
} 
Although they develop more gradually, they last for much longer periods than floods (often for years). An important component of adjustment to new climatic conditions could be an integrated water management, equally directed to the prevention of floods and droughts (Grobicki, A. et al. 2015; Ferk, M. et al. 2020). Water retention is a crucial task here (European Commission 2014; Ferk, M. et al. 2020). The damage brought about by extreme weather events always depends on the local context. As a good example, it could be cited that in Hungary 2010 was by far the most humid year since the beginning of meteorological observations, while 2011 was somewhat drier than anything observed before (KSH 2012). In most of the mesoregions of the country, however, thanks to the storage of surplus moisture from the previous year in soils, the 2011 drought did not cause remarkable losses of crop yield.

For long, throughout the $19^{\text {th }}$ and $20^{\text {th }}$ centuries, flood control measures meant cost-intensive construction of engineering structures (primarily dykes and embankments). Only recently the significance of natural processes in flood control has been recognized. Indicators of flood regulation demand (Хтӥвск, J. et al. 2014) allow the mapping of the distribution of areas with high flood regulation capacity, which is mostly due to close-to-natural vegetation or extensive agricultural use. The main limiting factor to flood regulation is the low water retention capacity of some soil types due to their texture, bulk density and organic matter content (CASTELlini, M. and Iovino, M. 2019). The relative weights of such parameters can be defined through sensitivity analyses (BAKACsI, Zs. et al. 2019).

It had not happened before the $21^{\text {st }}$ century either that the importance of water retention on floodplains was recognized within the framework of ecosystem services (FISHER, B. and Turner, K. 2008; Haines-Young, R. and Potschin, M. 2011; Dezsó, J. et al. 2019). This recognition induced a change of paradigm in water management: instead of getting rid of surplus water and conducting floods as rapidly as possible downstream, the main objective became the conservation of water- primarily in floodplains (Lóczy, D. 2013), but also, in small but cumulative amounts, in the upper sections of catchments (HüMANN, M. et al. 2011). The idea is that in these sections the rapid collection of run-off waters can be prevented applying relatively simple and low-cost investments before huge water masses could cause disastrous floods on lowland river sections (SEeger, M. and Ries, J.B. 2008). How can we create conditions more favourable for slow infiltration than for rapid run-off? Certain land use classes as well as landscape micro-features can be effective in this respect (SYrbe, R.-U. and Grunewald, K. 2013). Since the intensity of infiltration tends to decrease exponentially (or in a power fashion) with time, the first hours after rainfall (or sudden snowmelt) are of particular significance.

For an integrated and sustainable water basin management a reconsideration of the role of landscape pattern and water retention capacity is needed. Instead of cost-effective engineering solutions, which are often damaging to the aesthetic quality of the landscape (Jørgensen, D. and Jørgensen, F.A. 2018; Peng, S.H. and HAN, K.T. 2018), more natural, 'ecological', interventions are required (European Commission 2014), which also serve the goals of the EU Water Framework Directive and other guidelines (European Commission 2000, 2006, 2007). In the Natural Water Retention Measures (NWRM) directive the following goals are identified (European Commission 2014):

- parallel mitigation of flood and drought risk; - regulation of stream flow and surface run-off to intensify infiltration;

- enhancement of water storage in soils, standing water bodies and aquatic ecosystems;

- supporting positive natural hydrological processes.

All these measures underpin the resilience of ecosystem under conditions of climate change.

As conceived in the European Union, NWRM (European Commission 2014) comprises both traditional (waterways, retention ponds etc. - Declerck, S. et al. 2006) and novel solutions ('soft engineering' such as green infrastructure, bio-infiltration, rain gardens etc.) 
which are relatively easy to apply in urban (PYKe, C. et al. 2011) as well as rural environments (Emerson, C.H. et al. 2005; Davis, A.P. et al. 2009). The efficiency of retention measures should be carefully monitored in the context of the local environment (VÝLETA, R. et al. 2017).

A carefully chosen type of land use on hillslopes can be the best tool for run-off regulation (Leitinger, G. et al. 2010; Zucco, G. et al. 2014; Ribeiro, D. and Šmid Hribar, M. 2019). The modelling of run-off generation and water conservation under different agricultural land uses, modified by the spatial and temporal variability of soil physical properties, is a common topic of research in Europe (e.g. STOLTE, J. 2003), the United States (Guerrero, B. et al. 2017) and China (WANG, H. et al. 2013). The findings are applied in land-use planning.

In addition to the effect of land use on runoff, various authors have identified a range of manmade features in traditional landscapes (hedgerows, scarps on field margins, ploughland terraces, riparian belts) which are instrumental in run-off deceleration (BAUDRY, J. et al. 2000; Thiem, K. and Bastian, O. 2014; Šmid HribAR, M. et al. 2017) and have a number of other beneficial functions (wind shelter, conservation of air and soil moisture, soil erosion and pollution control etc.). In the $20^{\text {th }}$ century, the loss of traditional management practices has led to a large-scale impoverishment of the landscape (WEI, W. et al. 2016) and declining biodiversity (Haber, W. 2014). At the same time, some landscape elements prove to be persistent and survive. For instance, ploughland terraces (in German: Ackerterrassen) are still conspicuous elements of many agricultural landscapes (Lóczy, D. 1998). Even relict micro-topographic elements (occasionally with remnant vegetation patches) can modify slope processes (run-off, erosion, nutrient fluxes Zorn, M. and Komac, B. 2011; Centeri, Cs. et al. 2015) and are particularly highly appreciated in regions where water is in short supply (Chen, L. et al. 2013; Niv, C.Y. et al. 2015). It should be noted that occasionally escarpments and terraces completely deprived from vegetation are also efficient since the slope deposits which are often accumulated in considerable thickness store substantial amounts of moisture. Economic calculations confirm that their conservation is profitable: it is claimed that the expenses of conservation yield returns with 1.8-fold average profit in the future (THIEM, K. and Bastian, O. 2014).

Retention ponds on small watercourses help to reduce extreme water regime $(\mathrm{GoтоH}, \mathrm{H}$. et al. 2011; FERK, M. et al. 2020) and release floodwater gradually into major rivers (ScHoLz, M. 2003). The return of the expenses of such investments is also regarded favourable (IUCN 1997; Berry, P. et al. 2017). In Hungary, in the Transdanubian Hills numerous flood retention reservoirs (on many streams in a cascading system) were built in the 1970s. The largest, Lake Deseda, is capable to store 10.75 million $\mathrm{m}^{3}$ of water (CSER, V. 2019). Although it was built for the purposes of flood control and industrial water supply, the reservoir is of complex utilization, i.e. also used for fishing and angling, bathing, nature conservation, water sports and other recreation activities. These secondary functions, however, can occasionally conflict with the primary one. Although retention reservoirs are remarkable landscape features, their landscape ecological role has not been surveyed yet (FERK, M. et al. 2020).

The efficiency of resilient measures of flood control is excessively analysed in water management and landscape ecological literature (Kundzewicz, Z.W. et al. 2018). Run-off retention is one of the most important regulating ecosystem services from the viewpoint of water management (TEEB, 2010; Haines-Young, R. and Potschin, M. 2011; Laterra, P. et al. 2012; Horoszné Gulyás, M. 2012; SтÜRск, J. et al. 2014). A range of relatively easily established or maintained landscape features, including diversion or contour banks (DERM 2010), grassed waterways (Fiener, P. and Auerswald, K. 2003), vegetated ditches (Cooper, C.M. et al. 2004; Moore, M.T. et al. 2004; Отто, S. et al. 2016), hedgerows and other buffer strips (European Union 2014) are routinely used in landscape planning worldwide. Historical surveys are performed in the ongoing Hungarian national project on the mapping and evaluation 
of ecosystem services (MAES-HU - TANÁcs, E. et al. 2019). The three services selected for monetary evaluation also include water retention capacity.

The Topographic Wetness Index (TWI) developed by Beven, K.J. and KirKby, M.J. (1979) and further refined by BEven, K.J. (1986), identifies sites of run-off concentration on slopes and, thus, depicts the detailed spatial distribution of moisture storage. Plenty of experience is available on the applicability of the TWI, not only for run-off control (HJERDT, K.N. et al. 2004), but, for instance, for spatial vegetation pattern (Kорески́, M. and Č́́ž́̌vó, S. 2010), for delimiting inundated areas after urban flash floods (Pourali, S. et al. 2016) and for the spatial extension of NVDI index values (SHARMA, A. 2010). The index was found to be suitable for hilly areas but proven to be misleading in the case of broad floodplains and flat valley bottoms with deep sediments fills where large amounts of water are stored (Ali, G. et al. 2013). No experiments of this type have been performed so far in the Pannonian Basin.

The current paper presents the first findings of a joint Hungarian-Slovenian research project entitled "Possible ecological control of flood hazard in the hill regions of Hungary and Slovenia". According to the authors' knowledge no studies have been targeted the analysis of the impact of linear landscape elements on moisture retention in the Pannonian Basin. The project aims at filling in this scientific gap and exploring the opportunities of water retention in soils on hillslopes in a sustainable manner and without costly investments into hard engineering structures. In addition to the analysis of the impact of land use change, the impact of landscape features on water dynamics during the vegetative period of 2019 was also studied.

\section{Materials and methods}

\section{Study sites}

The three study areas are located in the Transdanubian Hills of Southwest Hungary in the vicinity of the city of Pécs (Figure 1). All three has relatively gentle slopes, similar soil parent materials (loess) and physical soil types. The agricultural land use types and landscape patterns (the preservation of traditional landscape elements), however, are different (ploughland, pasture and orchard).

\section{Boda area (foothills of the Mecsek Mountains)}

This study area is located about $10 \mathrm{~km}$ West of Pécs, in the southern foreland of the Mecsek Mountains, gently sloping towards the Pécs half-basin. Its elevation ranges from 172 to $182 \mathrm{~m}$. Typical land use is large-scale arable farming with conventional tillage, with sugar-beet, cereals, sunflower, soy and rape seed as the main crops. The prevailing diagnostic soil type of the site is Haplic Luvisol. The soil moisture monitoring sites were placed on a slope of 4.24 per cent inclination. It means that this surface can be regarded as almost horizontal, but the steepest slopes with southern or south-western exposure have angles up to 10 per cent. The distance between the upper and the lower monitoring sites is $190 \mathrm{~m}$. Erosion features in the study area include a derasional valley and an erosional stream with a small grove which influences soil moisture budget in the immediate vicinity of the valley. Heavy rainfalls between 3 and 16 July 2018 induced large-scale rill erosion on the surface. The annual rainfall of the area in 2019 totalled $630 \mathrm{~mm}$.

Palkonya area (northern foreland of the Villány Hills)

The second study area lies enclosed between the settlements of Palkonya, Ivánbattyán, Kisjakabfalva, Villány and Villánykövesd. The parent material is loess overlying a Mesozoic limestone basement. The soils are described as Chromic Cambisols. Elevation above sea level is somewhat lower than in 


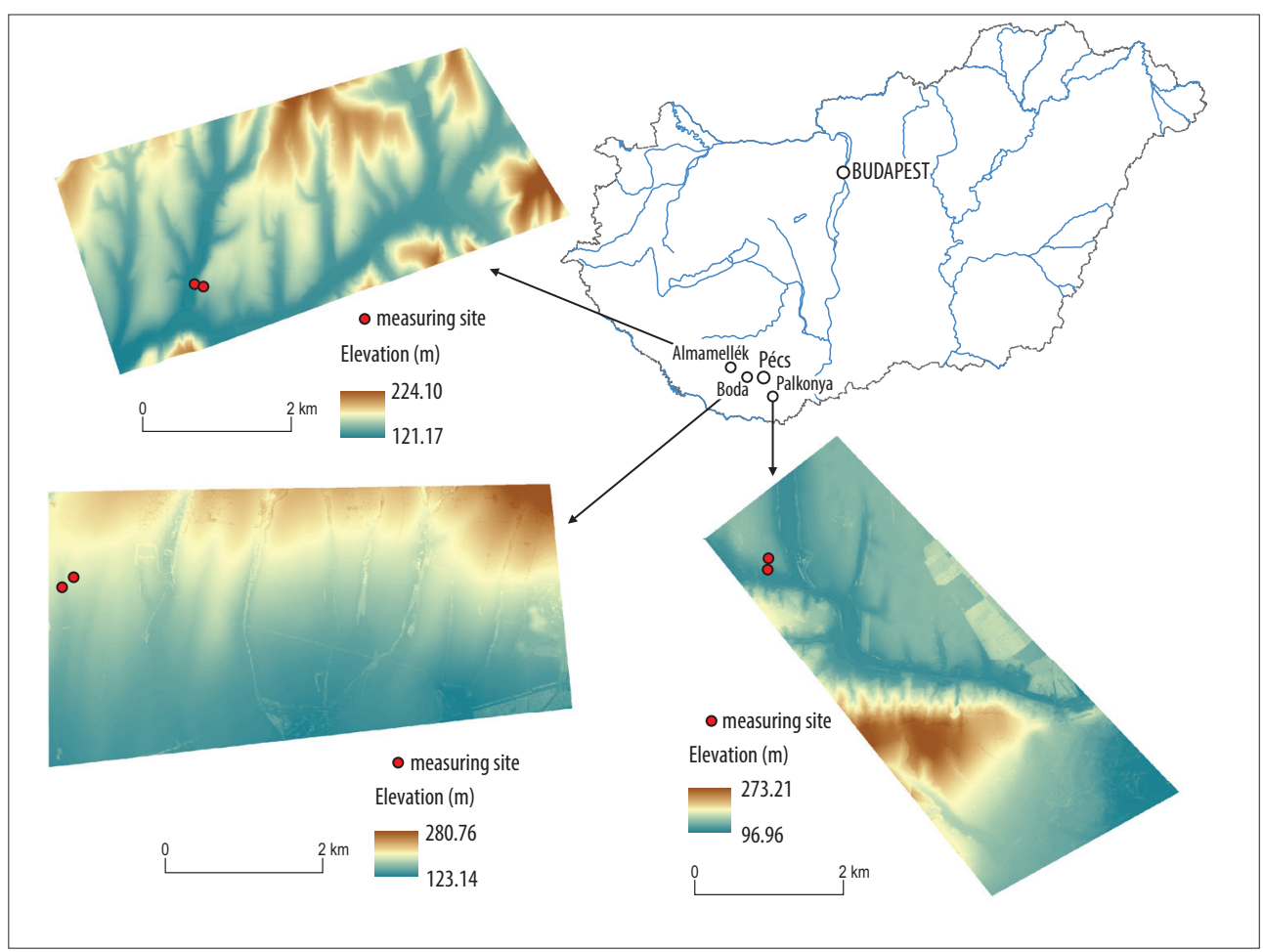

Fig. 1. Location of the study areas on the DEM generated from a LiDAR survey. a = Almamellék (meadow); $\mathrm{b}=$ Boda (arable land); $\mathrm{c}=$ Palkonya-Villánykövesd $($ orchard)

Boda, 113-128 m, while the plot where the monitoring equipment is placed is steeper, with an average slope of 8.98 per cent. Land utilization is partly orchard and partly grazing land. The measurement sites were deployed at a distance of $156 \mathrm{~m}$ from each other. The annual rainfall of the area in 2019 totalled $830 \mathrm{~mm}$.

\section{Almamellék area (Zselic Hills)}

The study area is situated in a basin of the Zselic Hills at an elevation of 127-142 m. Its relief is subdued (mean slope angle is $4.24 \%$ ) but still slightly dissected. The Calcaric Phaeozem soils of the site are locally severely eroded. (The Hungarian Agricultural Plot Registration Database [MePAR] indicates medium to severe water erosion hazard for ca $40 \%$ of the study area.) The valleys are used as meadows and hillslopes mostly as grazing land. The measurement sites are located at a distance of $167 \mathrm{~m}$ from each other. The soil and water conservation measures implemented by landowners to date have not proved to be efficient. The most significant rainfall event of the past decades was observed in March 2018 with a total rainfall of $128 \mathrm{~mm}$ recorded by the rain gauge of the neighbouring Szentlászló which threefold exceeded the long-term March average. A rapid and sediment-loaded run-off washed down huge amounts of loess along dirt roads used by agricultural vehicles into concrete-lined water-conducting ditches even plugging culverts. The annual rainfall of the area in 2019 totalled $770 \mathrm{~mm}$. 


\section{Generation of the $T W I_{L U}$ maps}

For a comprehensive assessment of the water dynamics the Water Retention Index (WRI) was employed, which is a useful tool to estimate potential water retention broken down to water storage by the various landscape components (VANDECASTAELE, I. et al. 2016; Qiu, Z. et al. 2017; RAduŁA, M.V. et al. 2018). The WRI is calculated using the following equation:

$W R I=\left(w_{v} R_{v}+w_{g w} R_{g w}+w_{s} R_{s}+w_{s l} R_{s l}+w_{w b} R_{w b}\right) \cdot\left(1-\frac{R_{s s}}{100}\right)$,

where $w$ is the weight to be assigned to each parameter (subscript $v$ is vegetation, $g w$ is groundwater, $s$ is soil, $s l$ is slope and $w b$ stands for surface water bodies), and $R$ is the parameter scores given for retention in vegetation $\left(R_{v}\right)$, groundwater bodies $\left(R_{g w}\right)$, soil $\left(R_{s}\right)$ and surface water bodies $\left(R_{w b}\right)$, and for slope $\left(R_{s l}\right)$ and soil sealing $\left(R_{s s}\right)$. The values of the component factors of the equation were estimated from findings of other research projects in Hungary (Kertész, Á. et al. 2010; JuHos, K. et al. 2019).

An indispensable precondition for the experiments carried out in the study areas was a Digital Elevation Model (DEM) of proper resolution. While a 1-m resolution DEM based on LiDAR survey for the territory of Slovenia (ŽvoKELJ, B.P. et al. 2015) was at the disposal of the Slovenian partners, unfortunately, for the territory of Hungary no such suitable DEM was available. Therefore, as a first step a LiDAR survey and the subsequent data processing into a DEM was ordered and carried out by the Envirosense Hungary Ltd. The limitations of project financing only allowed for the survey to cover three study areas, $11-12 \mathrm{~km}^{2}$ each.

In principle a DEM can be applied to depict soil moisture conditions because water flow tends to follow topographic gradients and accumulate in response to gravitational potential energy (MurPHy, P.N.C. et al. 2009). Therefore, for reconstructing the spatial distribution of moisture storage and the sites where surface run-off is concentrated, the Topographic Wetness Index (TWI) is widely used (Beven, K.J. and Kirkby, M.J. 1979).
TWI is a GIS-based index which can be derived from any grid with elevation data and is able to indicate the soil moisture conditions and water retention potential, solely based on topography. Relying solely on the DEM, the TWI ${ }_{\text {DEM }}$ only identifies the sites of natural run-off concentration and the resulting distribution of soil moisture. This way the importance of topography is exaggerated and, at the same time, the role of land use is disregarded. Eventually, TWI relies on a high-resolution DEM and calculates water and soil moisture distribution only from the size of the catchment area and slope inclination as input parameters, using the following equation:

$$
T W I=\ln (a / \tan \beta),
$$

where $a$ is the number of DEM pixels above the point of observation (representing the catchment area) and $\beta$ is slope inclination (in degrees). TWI is a dimensionless figure, which ranges from 0 to 30 . Values close to 0 indicate dry areas, while those above 20 wet areas. In the light of previous investigations (see e.g. Murphy, P.N.C. et al. 2009; Drover, D.R. et al. 2015; Tномаs, I.A. et al. 2017), special attention should be devoted to the quality of input data for TWI, primarily to their resolution. Experiences with the application of TWI confirmed that calculation merely corresponds with topography and cannot realistically reflect soil moisture conditions. Therefore, as a further developed version, Beven, K. and Wood, E.F. (1983) and Beven, K.J. (1986) suggested a Soil Topographic Wetness Index (STWI), which also takes into account soil and sediment transmissivity (in the saturated zone below the groundwater table):

$$
S T W I=\ln (a / T \cdot \tan \beta),
$$

where $T$ is soil and sediment transmissivity (below groundwater table) measured in $\mathrm{m}^{2} \mathrm{~h}^{-1}$. From the DEM $\tan \beta$ is the slope, while the value of $\tan \beta=\partial / \partial L$ is more applicable for the evaluation of biodiversity and soil $\mathrm{pH}$ (Sørensen, R. et al. 2006). 
TWI index values were calculated with ArcGIS 10.4 software. The input model was the DEM generated from LiDAR survey data and the Digital Surface Model (DSM) of 1-metre resolution. The latter dataset included the first reflectance of the radar signals, and, therefore, comprises all natural and artificial objects (in other words, DSM represents the elevations of the reflective surfaces [trees, buildings and other features] which rise above the ground surface - ZHоu, Q.M. 2017).

Natural water retention potential was assumed to be proportional with the difference between the TWIs calculated from the DEM and from the DSM. It was supposed that the features of micro-topography with water retention potential have some (even if minimal) spatial extension and, therefore, are represented in the DSM as higher-lying surfaces. Subtracting the elevations of pixels in the DSM-derived TWI from the DEM-derived TWI, the difference can be any value (negative, positive or zero). To avoid results of negative values, the minimum grid value $(m)$ in the investigated area (always negative) is subtracted from the difference of the DEM and DSM derived TWI. The new TWI applied for land use $\left(T W I_{L U}\right)$ is calculated grid by grid using the following equation:

$$
\left.T W I_{L U}=T W I_{D E M}-T W I_{D S M}\right)-m,
$$

where $T W I_{L U}$ is water retention potential; $T W I_{D E M}$ is TWI grid value derived from the DEM; TWI ${ }_{D S M}$ is the TWI grid value derived from the DSM; $m=\min \left(T W I_{D E M}-T W I_{D S M}\right)$ is the minimum value of the difference between $T W I_{D E M}$ and $T W I_{D S M}$ within the study area. The grid values therefore can only be positive numbers or zero. As a consequence, values ranging from 0 to the median value can be regarded to indicate areas with low water retention potential, while areas with values ranging from the median to the maximum value are designated as areas with high water retention potential.

\section{Field monitoring setup}

To validate the soil moisture model in the context of the local landscape pattern, soil moisture monitoring systems were installed for each study area in December 2018. Rainfall totals and intensities were collected using tipping-bucket rain gauges (ECRN-100, Meter Group Inc., Pullman, WA, Unites States) of $0.2 \mathrm{~mm}$ resolution. Rain gauges were installed only at the top of slopes of plots. At both the top and bottom of each monitored slopes TDR soil moisture sensors (Meter Group Inc., Teros 12) and tensiometers (Teros 21) were horizontally inserted into the soil at depths of 10 and $30 \mathrm{~cm}$. All data were collected with EM-60 data logger in 15-minute time intervals.

For the spatial calibration of the model, Volumetric Water Content (VWC) was measured with a Fieldscout TDR-300 soil moisture meter (Spectrum Inc., Planfield, Illinois, United States) in June 2020, following a dry winter and spring (184, 175, 195 and $187 \mathrm{~mm}$ rainfall totals between January 1 and May 31, 2020 in Pécs, Almamellék, Boda and Palkonya, respectively). Fifty measurements of three repetitions at each measurement point were taken at the three sites using $20-\mathrm{cm}$ long electrodes. Spearman analysis was employed to compare $\mathrm{TWI}_{\mathrm{LU}}$ maps with the field measured data.

\section{Particle size analysis of the soil samples}

Soil samples were taken from the depths of 10 and $30 \mathrm{~cm}$. Samples were then pre-treated for the removal of organic matter and $\mathrm{CaCO}_{3}$ in the soil science laboratory of University of Pécs. Textural pattern and particle size distribution of the soil samples were determined using a Malvern MasterSizer 3000 (Malvern Inc., Malvern, England, United Kingdom) particle size analyser.

\section{Results and discussion}

\section{Distribution of TWI indices in the study area}

According to former studies land use plays an important role on the spatial distribution of soil moisture. To this purpose, the DSM 
(controlled by land use) was integrated into the DEM to create a combined DEM-DSM (called $\mathrm{TWI}_{\mathrm{LU}}$ in the current study), uniting moisture dynamics (water retention) originating from topography and from land use. Therefore, the calculated $\mathrm{TWI}_{\mathrm{LU}}$ was used to depict the spatial distribution of soil moisture in the three study sites.

$\mathrm{TWI}_{\mathrm{LU}}$ maps showed patterns noticeably different from those on either $T W I_{D E M}$ or $T W I_{D S M}$ maps (Figure 2). The obtained TWI maps indicated the potential run-off paths which were due to the joint effect of topography and vegetation (land use) in the three study areas. In addition to micro-topography, the $\mathrm{TWI}_{\mathrm{LU}}$ also indicated the influence of landscape features, in the case of the orchard, tree rows, on run-off reduction and moisture storage (see Figure 2). $\mathrm{TWI}_{\mathrm{LU}}$ distinctly pointed out the combined role of surface elevation and vegetation (elevated surfaces) on the spatial distribution of soil moisture in the three study areas.

The overall highest TWI value was detected at the Almamellék site (28.080). The $\mathrm{TWI}_{\mathrm{LU}}$ map indicated low TWI values at the abrupt step (location of the top slope station) of about two metres vertically at the top of the Almamellék site and at the dirt road in an upslope direction. Although enhanced lateral evaporation was expected here in the profile, tension did not fall below the permanent wilting point (PWP, $-1,500 \mathrm{kPa}$ ) during the entire monitoring campaign. It is likely explained by the low infiltration and lower roughness values of the road which enhance run-off in the direction of the step and the tensiometers. The site of the bottom slope station here was not properly selected and should have been positioned in the main stream of moisture accumulation about $65 \mathrm{~m}$ to the south. However, if located closer to the fish ponds the effect of groundwater would be more pronounced on moisture contents.

The $\mathrm{TWI}_{\mathrm{LU}}$ grid values of the Boda site were the lowest among the three sites with a maximum pixel value of only 17.754. Here the $\mathrm{TWI}_{\mathrm{LU}}$ map indicated pixels of high moisture contents for both monitoring sta- tions, due to the proximity of the hedgerow upslope of the top slope station and the influence of the grove upslope of the bottom slope station. Still, this site was exposed to the greatest water stress over the monitoring campaign with tension below PWP for the longest period. Here, the lack of crop cover, following the harvest, likely contributed to the low matric potential values. However, additional moisture and tension data were not available to compare the two stations with in-site moisture data where micro-features did not influence moisture dynamics.

At the Palkonya site soil moisture showed moderate variations (TWI values ranged between 0 and 21.53). The most prominent pattern was observed at the orchard site where the tree rows influenced soil-atmosphere interactions via the differences in direct irradiation and evapotranspiration. The TWI index allowed a clear distinction between surfaces with the predominance of run-off and those with high water retention capacities. The latter mostly coincide with the rows of trees (see Figure 2). Run-off in the orchard was diverted into the alleys between tree rows, while canopy differentiated water retention through interception, shading effect and evapotranspiration, hence modifying the infiltration/ run-off ratio. Nonetheless, in a considerable portion of the Palkonya site, spots of high water retention were not parallel with the tree rows. This fact underlines the modifying effect of natural micro-features in relief. This heterogeneous moisture pattern is pointed out in the $\mathrm{TWI}_{\mathrm{LU}}$ model, however it does not always reflect higher water retention capacities along the tree rows compared to the interrows (Figure 2, i).

Soil moisture and tension distribution based on field monitoring

Monitored matric potential $\left(\psi_{m}\right)$ data for the spring period revealed that capillary rise (upward water motion) was the dominant process at the upper sites while at the footslopes infiltration (downward water motion) dominated moisture dynamics (Figure 3). Matric potential 


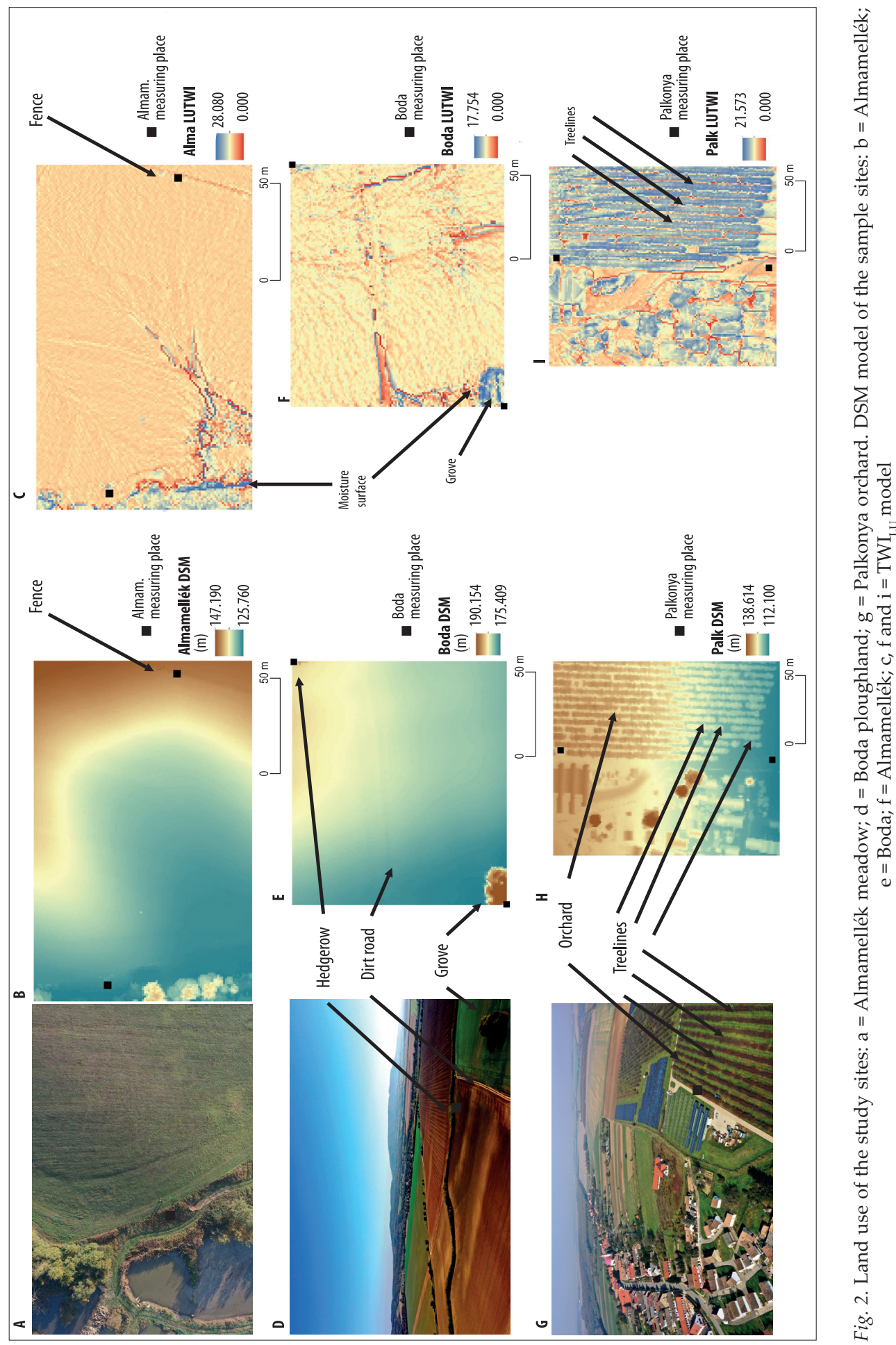


$\infty$

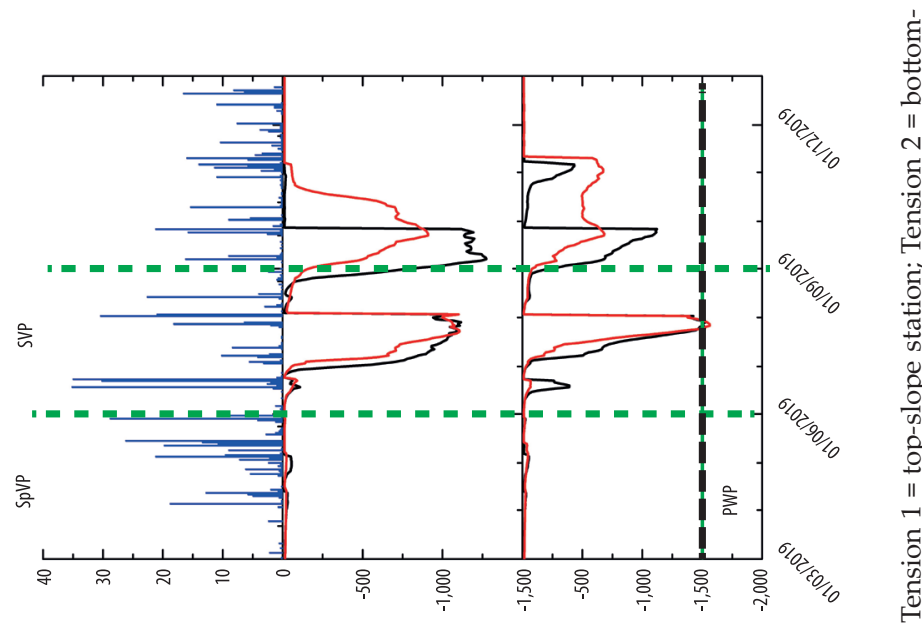

$\checkmark$
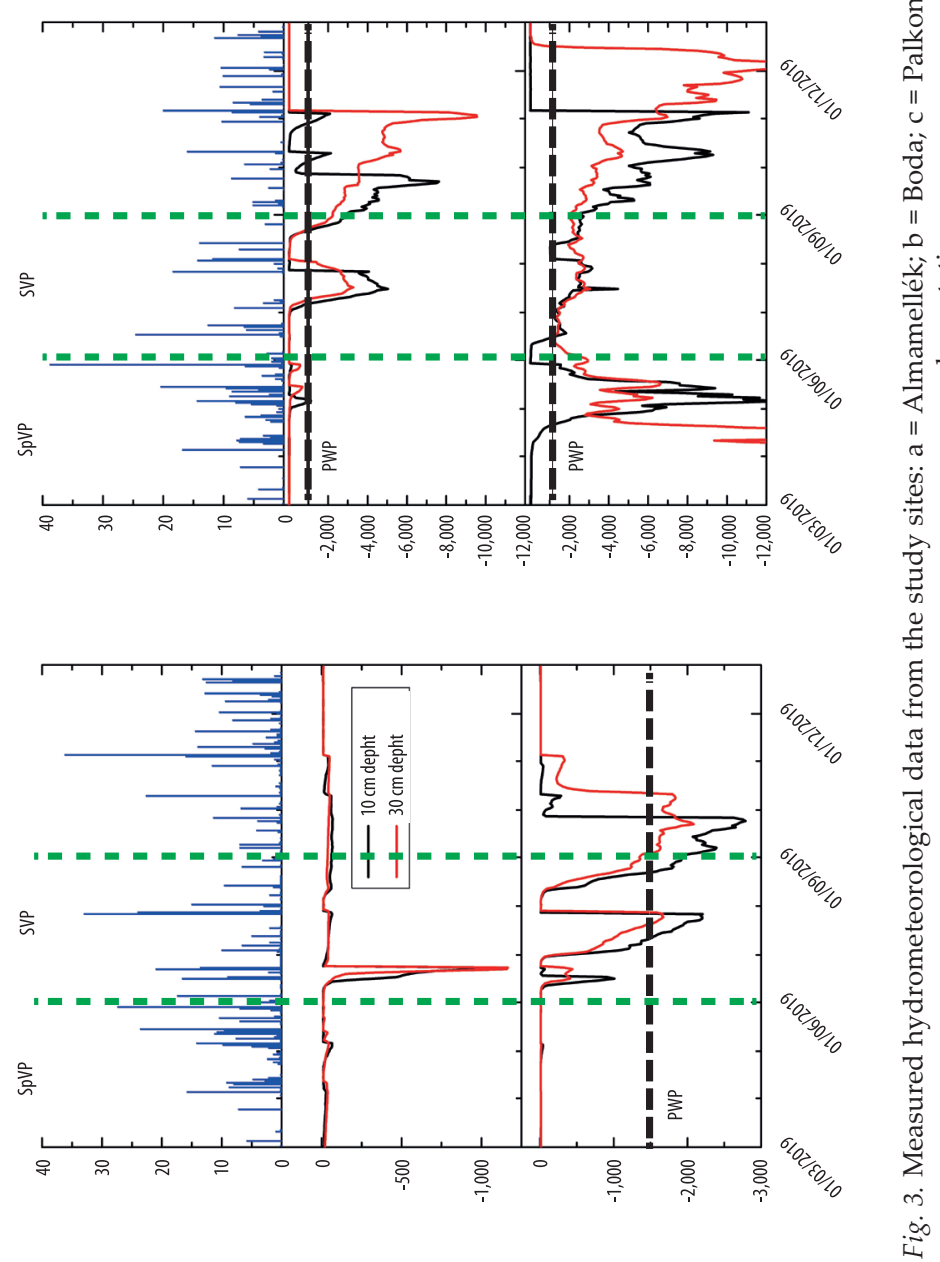
values observed at the three study sites were remarkably different over the investigation period. Similarly, differences in water potentials were striking between the spring and summer periods of the growing season.

There was no significant difference between the fluctuation of the top-slope and bottom-slope potential values during the spring season at the Almamellék site. Here, tension values did not fall below the PWP. Prolonged periods devoid of rainfall triggered the plunging of water potential from $-20 \mathrm{kPa}$ to $-1,300 \mathrm{kPa}$ between July 1 and 13, 2019, at both the top-slope and the bottomslope station. However, for the rest of the summer water potential at the top-slope site did not fall below $-250 \mathrm{kPa}$. Water potential at the bottom-slope station fell below the PWP twice. Former studies also concluded that usually there are two periods of drought hazard in Hungary (Kocsis, T. and ANDA, A. 2006). However, no rainless period exceeded 15 days over the study period.

The Boda site is utilized for dryland farming, hence it remains uncovered by crops for a prolonged period of time between September and April (see Figure 2). This plot is bordered by a hedgerow to the northeast, while a grove borders the plot to the southwest: these features significantly mitigate run-off at the aforementioned boundaries of the studied plot. Mean tension values in the spring, measured next to the hedge, were higher $(-25 \mathrm{kPa})$ than next to the grove $(-65$ $\mathrm{kPa}$ ) (Figure 3, b). While tension did not fall below the PWP during the spring, there were no plant available water next to the grove in the top $30 \mathrm{~cm}$ between March 28 and May 28 . Water potential fluctuations were an order of magnitude higher next to the grove than at the hedge. During this period, two rain-free spells lasted for 10 days (March 26 to April 4) and April 15 to 24). During the summer water potential fell below the PWP at both the hedge and the grove. Tension remained below the PWP for the entire summer at the grove. Although tension also fell below PWP at the edge of hedgerow, a major difference was observed between the length of drought- affected period between the top-slope and the bottom-slope sites. The grove matric potential remained below $-1,500 \mathrm{kPa}$ during the entire period at a depth of $30 \mathrm{~cm}$, and even further decreased till mid-November (Figure 3, c). Sub-PWP tensions abruptly ceased on October 30, 2019, at both top-slope depth and at a depth of $10 \mathrm{~cm}$ at the bottom slope (grove) when tensions increased due to a rainfall event of $10.3 \mathrm{~mm}$. However, tension at a depth of $30 \mathrm{~cm}$ at the grove remained below the PWP. At the hedgerow two distinct drought period was identified: the first between July 8 to 27 and a second between August 27 to September 27.

At the Palkonya site, the top-slope station is located among the trees while the bottom-slope station is found $8 \mathrm{~m}$ downhill from the base of the orchard (see Figure 2, c). During spring tension was never less than $-25 \mathrm{kPa}$ (note that the moist-end measurement limit of Teros 21 is around $8 \mathrm{kPa}$ ). Fluctuation of tension was almost negligible in the spring months. Over the summer top-slope tension never fell below the PWP, yet tension decreased from $-33 \mathrm{kPa}$ to $-1,104 \mathrm{kPa}$. Tension at the bottom-slope station, however, reached the PWP for 3 consecutive days between July 27 and 29, 2019.

\section{Water stress sensitivity}

Our research validated former results (EмERson, C.H. et al. 2005; DAvis, A.P. et al. 2009; Leitinger, G. et al. 2010; Syrbe, R.-U. and GrunewAld, K. 2013; WANG, S. et al. 2013; Zucco, G. et al. 2014; VýletA, R. et al. 2017), i.e. soil moisture is closely controlled by land use, the proximity of land features, precipitation totals and intensities and soil textural properties. During our monitoring campaign precipitation totals of less than $1 \mathrm{~mm}$ per day did not affect matric potential. In terms of temporal variability of matric potential of the topsoil, two significant periods, characterized by large fluctuations and relatively low tension, were observed at all three study sites. Tension only fell below the PWP at the ploughland and the meadow sites, while 
reached the PWP at the bottom-slope station of the orchard. Largest variability of matric potential was observed at the grove-ploughland and the hedge-ploughland boundaries. At the meadow site the bottom slope was affected by medium tension fluctuation while the orchard bottom-slope tension was only slightly sensitive and exposed the vegetation to only a slight water stress. Presumably, the grove and the hedgerow functions as a water retention barrier during run-off events, whereas during periods of water stress they may further decrease soil moisture contents and the matric potential of the top $30 \mathrm{~cm}$ of the soil. Although rainless periods were always shorter than 15 days, which contradicts the findings of Kocsis, T. and ANDA, A. (2006), agricultural an economic drought was still extensive, especially at the tilled site. Land use change does not actually eliminate the appearance of drought but shortens its duration and mitigates its impact on vegetation.

In the spring period the most favourable soil water budget was observed in the grazing land of Almamellék, where average soil moisture content was the highest in summer. Drought risk in summer was the highest in the Boda area. Soil moisture contents were low on many occasions and for prolonged periods. The longest of such periods lasted for 46 days (between June 17 and August 2, 2019). During summer the Palkonya orchard, a close-to-natural type of agricultural land use, had the highest average soil moisture content, particularly if we compare it with the built-up area in its western neighbourhood. This finding confirms that even very sparse, village-type, housing development may have a considerable negative impact on moisture conditions (see Figure 3). Analysing the interrelationships between precipitation and tension, for the Palkonya area it was found that rainfall events above $1 \mathrm{~mm}$ could cause observable changes in tension of the upper soil horizon.

Soil moisture distribution influences soil formation processes on the long run. Depending on the season and the morphological position remarkable differences are observed in the direction of water motion (infiltration versus capillary rise). At the measurement sites water tensions at 10 and 30 $\mathrm{cm}$ depths as well as their temporal changes differed conspicuously between the upper and the lower sites of measurement. The footslope sites invariably had less negative matric potentials. It was found that in spring capillary rise can alternate with infiltration along the same slope. The limited surface run-off observed at all the three areas can be explained by the low rainfall intensities and gradual snowmelt. During the summer part of the growing season capillary rise was common for both measurement sites. Horizontal flow (surface run-off and probably throughflow too) has intensified in the summer compared to spring. This particularly applies to major showers (e.g. on June 18, 2019: 35.2 mm day ${ }^{-1}$, on August 3, 2019: $30.4 \mathrm{~mm} \mathrm{day}^{-1}$ ).

Our results revealed a weak correlation between elevation and field measured VWC for the orchard (Palkonya site), moderate correlation for the ploughland (Boda site) and strong correlation for the pasture of the Almamellék site (Table 1). TWI $\mathrm{LU}_{\mathrm{Lu}}$ performed well pointing out spatial variation in soil moisture conditions and dynamics at the orchard site, as $\mathrm{TWI}_{\mathrm{LU}}$ integrated both the effects of topography and vegetation. By accounting for the shading effect and retention of moisture under canopy, $\mathrm{TWI}_{\mathrm{LU}}$ well reflected actual moisture contents of the top $20 \mathrm{~cm}$ of the studied soils. When elevation was correlated with the $\mathrm{TWI}_{\mathrm{LU}}$, the orchard showed the highest correlation and the pasture the weakest, demonstrating the adequacy of $\mathrm{TWI}_{\mathrm{LU}}$ for a land use type of this sort. When the measured VWC was correlated with $\mathrm{TWI}_{\mathrm{LU}^{\prime}}$ negative correlation was found

Table 1. Correlations among elevation, VWC and $T_{W U}$ for the three studied land use types

\begin{tabular}{l|c|c|c}
\hline \multicolumn{1}{c|}{ Parameters } & Ploughland & Orchard & Pasture \\
\hline Elevation - VWC & 0.573 & 0.354 & 0.726 \\
Elevation - TWI $_{\text {LU }}$ & 0.357 & 0.790 & 0.087 \\
VWC - TWI $_{\text {LU }}$ & -0.438 & 0.412 & 0.139 \\
\hline
\end{tabular}

Note: VWC was measured during an extreme dry period in June 2020. 
for the ploughland while the best correlation was observed again for the orchard site. The negative correlation demonstrates water retention in upslope and midslope position, likely indicating the influence of linear elements (a grove and a hedgerow) in the intensively cultivated landscape which counteracts and reduces the downslope movement of soil moisture due to gravity.

According to our findings, the most favourable soil water conditions have been observed in the grazing land and orchards (particularly tree rows), as they were identified as places of high water retention capacity. These findings have been partly corroborated by the conclusions of WANG, H. et al. (2013) who claim that grasslands in Eastern China had the highest infiltration rates preceding shrubs, subshrubs, trees and crops. However, mean soil moisture contents were only the second highest in their study and were lower than under maize canopy. According to VÝleta, R. et al. (2017) linear elements (e.g. tree rows and hedgerows), perpendicular to slopes, stabilize the surface, prevent soil denudation and mitigate direct run-off and water erosion, while, at the same time, contribute to increased infiltration. According to our findings, however, tree rows parallel to the slopes also mitigate run-off, and, combined with the shading effects of tree canopies, induce higher soil moisture contents compared to interrows.

Furthermore, Davis, A.P. et al. (2009) based on the result of their case study, suggest the strategic use of surface vegetation to divert and reduce surface flow and to filter sediments. Emerson, C.H. et al. (2005) sound the view that the volume control of peak run-offs in watersheds of high relief solely by detention basin is ineffective, unless combined with other alternative land use and run-off management practices. In accordance with the latter statement, Hinman, C. (2005) points out the necessity of sustainable practices and low-impact technologies on complex stormwater management. Similarly to EMERSon and his co-workers, we found that run-off volume can be controlled by grasslands and pastures, which contributes to increased infiltration and mitigate direct run-off.

Leitinger, G. et al. (2010) found that the greater the initial soil moisture content, the smaller the influence of slope gradient on run-off and infiltration remained. This finding was also confirmed by our results: increased infiltration was observed at lower initial matrix potential values. However, LEITINGER and his colleagues attributed particular importance to the seasonal dynamics of surface run-off and the land use type in their experiments performed in the Stubai Valley, Eastern Alps, Austria. Their experiments, in contrast to our results, revealed that macropore flow was inhibited on pastures due to the compaction exerted by cattle. The change in bulk density at depths of 0 and $0.2 \mathrm{~m}$ may have affected water holding capacities and recharge rates at the intensively cultivated Boda study site in or experiments. Hence, structural changes and increased soil bulk densities reduce macropore volume, macropore flow and soil moisture recharge. This also suggests that trampling, treading and mechanical load by heavy machinery may affect soil structure, which may be avoided by various BMPs including conservation tillage or no-till techniques (e.g. Fuentes, J.P. 2004).

In contrast to the findings of TölgYesi, $\mathrm{C}$. et al. (2020), we did not observe the desiccating effect of trees on lower soil layers. This is partly explained by the difference in soil textural types as the aforementioned study found the drying effect in soils of sandy textures. On the contrary, our results revealed that in the case of the orchard trees, canopy and the shaded area enhances water retention and water storage during dry periods and therefore contributes to the general functions of natural ecosystem services. This finding is in a good agreement with those of Syrbe, R.-U. and Grunewald, K. (2013), and Ribeiro, D. and Šmid Hribar, M. (2019), who accredit high ecological importance to semi-natural line elements in the management of excess storm water. According to Guerrero, B. et al. (2017), in harmony with 
our findings, also suggest that natural agricultural water conservation strategies are capable to limit the decline of water and soil moisture supplies at regional scales. In addition, and rather similarly, our results pointed out the importance of natural landscape elements, providing ecosystem services, on the spatial distribution of soil moisture and water retention at sub-regional plot scales.

\section{Conclusions}

Our field monitoring results revealed that soil moisture at depths of 10 and $30 \mathrm{~cm}$ did not fully correspond with the spatial pattern of neither the TWI ${ }_{\text {DEM }}$ nor the currently presented $\mathrm{TWI}_{\mathrm{LU}}$. Rather unexpectedly, fieldmonitored data always indicated lower (more negative) tension values for the bottom slope sites than for the top-slope sites (see Figure 3). Naturally, this pattern contradicts the pattern of $\mathrm{TWI}_{\mathrm{DEM}}$ and $\mathrm{TWI}_{\mathrm{LU}}$ as both calculation algorithms assume the influence of gravity on moisture dynamics. This discrepancy can be partially explained by the influence of linear pedological and vegetational features and landscape elements (like in the case of the Almamellék site, with an anthropogenic step at the top of the slope) on the distribution of soil moisture, not fully reflected in the $\mathrm{TWI}_{\mathrm{LU}}$ map.

A second possible reason for the observed discrepancy is the insufficient resolution of field monitored data. To improve the spatial resolution of soil moisture distribution, point soil moisture measurements were taken using a mobile TDR device. The latter highresolution soil moisture measurements corroborated the large spatial heterogeneity of soil physical properties (texture, macropores, and preferential flow paths) in the field as well as the influence of landscape elements on soil moisture dynamics.

A third explanation for the difference in soil moisture pattern between the field pattern and the $\mathrm{TWI}_{\mathrm{LU}}$ map is the large spatial heterogeneity of soil physical patterns, especially the difference in soil texture. Therefore, the careful selection of the long-term soil moisture and water potential monitoring sites is essential. Alternatively, as mentioned in the previous paragraph, mobile monitoring of topsoil moisture conditions could provide a substitute solution for field data acquisition.

A fourth reason for the possible deviation between the TWI maps and the field data lies in the relatively short equilibrium time that was available for the sensors after deployment. The insufficient contact between the sensors and the presence of voids around the sensor discs might have supplied erroneous tension data. Therefore, longer periods of field monitoring, and higher cumulative infiltration totals and the subsequent compaction of soil particles are essential to verify and obtain an objective overview of field soil moisture patterns.

Acknowledgements: Authors are grateful for the financial support from the National Research, Development and Innovation Office (NKFIH) within the framework of the Hungarian-Slovenian collaborative project "Possible ecological control of flood hazard in the hill regions of Hungary and Slovenia" (contract no SNN 125727) and within the framework of the programme Excellence in Higher Education, Theme II. 3. ("Innovation for sustainable life and environment"). The authors acknowledge the study was performed in the frame of a project Possible ecological control of flood hazard in the hilly regions of Hungary and Slovenia. The project was financially supported by the Slovenian Research Agency (ARRS, N6-0070).

\section{REFERENCES}

Ali, G., Birkel, C., Tetzlaff, D., Soulsby, C., McDonnell, J.J. and TArolli, P. 2013. A comparison of wetness indices for the prediction of observed connected saturated areas under contrasting conditions. Earth Surface Processes and Landforms 39. (3): 399-413. Doi: 10.1002/esp.3506

Bakacsi, Zs., Tóth, T., Makó, A., Barna, G., Laborczi, A., Szabó, J., Szatmári, G. and PÁsztor, L. 2019. National level assessment of soil salinization and structural degradation risks under irrigation. Hungarian Geographical Bulletin 68. (2): 141-156. Available at https://doi.org/10.15201/hungeobull.68.2.3

Baudry, J., Bunce, R.G.H. and Burel, F. 2000. Hedgerows: An international perspective on their origin, function and management. Journal of Environmental Management 60. 7-22. Doi: 10.1006/jema.2000.0358 
Berry, P., Yassin, F., Belcher, K. and Lindenschmidt, K.E. 2017. An economic assessment of local farm multi-purpose surface water retention systems under future climate uncertainty. Sustainability 9. 456-478. Doi:10.3390/su9030456

Beven, K.J. and Kirkby, M.J. 1979. A physically based, variable contributing area model of basin hydrology. Hydrological Science Bulletin 24. (1): 43-69. Doi: 10.1080/02626667909491834

Beven, K. and Wood, E.F. 1983. Catchment geomorphology and the dynamics of run-off contributing areas. Journal of Hydrology 65. 139-158. Doi: 10.1016/0022-1694(83)90214-7

Beven, K.J. 1986. Run-off production and flood frequency in catchments of order $\mathrm{n}$ : an alternative approach. In Scale Problems in Hydrology. Eds.: Gupta, V.K., Rodriguez-Iturbe, I. and Wood, E., Dordrecht, Reidel, 107-131.

Castellini, M. and Iovino, M. 2019. Pedotransfer functions for estimating soil water retention curve of Sicilian soils. Archives of Agronomy and Soil Science 65. (10): 1401-1416. Doi: 10.1080/03650340.2019.1566710

Chen, L., Sela, S., Svoray, T. and Assouline, S. 2013. The role of soil-surface sealing, microtopography, and vegetation patches in rainfall-run-off processes in semiarid areas. Water Resources Research 49. (9): 5585-5599. Doi: 10.1002/wrcr.20360

Centeri, Cs., Szalai, Z., Jakab, G., Barta, K., Farsang, A., SzAbó, Sz. and Bíró, Z. 2015. Soil erodibility calculations based on different particle size distribution measurements. Hungarian Geographical Bulletin 64. (1): 17-23. Available at https://doi.org/10.15201/ hungeobull.64.1.2

Cooper, C.M., Moore, M.T., Bennett, E.R., Smith, S. Jr., Farris, J.L., Milam, C.D. and Shields, F.D. JR. 2004. Innovative uses of vegetated drainage ditches for reducing agricultural run-off. Water Science Technology 49. (3): 117-123.

Cser, V. 2019. 45 éve kezdték építeni a Deseda-tározót (The Deseda Reservoir began to be built 45 years ago). Pécs, DDVIZIG, A Drávától a Balatonig 3. 34-35. (in Hungarian)

Czigány, Sz., Pirkhoffer, E., Balassa, B., Bugya, T., Bötкös, T., Gyenizse, P., Nagyváradi, L., Lóczy, D. and Geresdi, I. 2010. Villámárvíz mint természeti veszélyforrás a Dél-Dunántúlon (Flash floods as a natural hazard in Southern Transdanubia). Földrajzi Közlemények 134. (3): 281-298.

Davis, A.P., Hunt, W.F., Traver, R.G. and Clar, M. 2009. Bioretention technology: overview of current practice and future needs. Journal of Environmental Engineering ASCE 135. 109-117. Doi: 10.1061/ (asce)0733-9372(2009)135:3(109)

Declerck, S., de Bie, T., Ercken, D., Hampel, H., Schrijvers, S., van Wichelen, J., Gillard, V., Mandiki, R., Losson, B., Bauwens, D., Keijers, S., Vyverman, W., Goddeeris, B., De Meester, L., Brendonck, L. and Martens, K. 2006. Ecological characteristics of small farmland ponds: Associations with land use practices at multiple spatial scales. Biological Conservation 131. 523-532. Doi: 10.1016/j.biocon.2006.02.024

DERM 2010. Run-off control measures for erosion control in cropping land. Brisbane, AUS, Department of Environmental and Resource Management, Government of Queensland. Available at https:// www.hort360.com.au/wordpress/uploads/Run_Off/ Control_Measures/Run_off_control_measures_for_ erosion_control.pdf

Dezső, J., Lóczy, D., Salem, A.M. and Nagy, G. 2019. Floodplain connectivity. In The Drava River: Environmental Problems and Solutions. Ed.: Lóczy, D., Cham, Switzerland, Springer International Publishing, 215-230. Doi: 10.1007/978-3-319-92816-6_14

Didovets, I., Krysanova, V., Bürger, G., SnizhKo, S., Balabukh, V. and Bronstert, A. 2019. Climate change impact on regional floods in the Carpathian region. Journal of Hydrology: Regional Studies 22. 100590. Doi: 10.1016/j.ejrh.2019.01.002

Drover, D.R., Jackson, C.R., Bitew, M. and Du, E. 2015. Effects of DEM scale on the spatial distribution of the TOPMODEL topographic wetness index and its correlations to watershed characteristics. Hydrology and Earth System Science Discussions 2015. 11817-11846. Available at https://doi.org/10.5194/ hessd-12-11817-2015

Emerson, C.H., Welty, C. and Traver, R.G. 2005. Watershed-scale evaluation of a system of storm water detention basins. Journal of Hydrological Engineering 10. 237-242. Doi: 10.1061/(ASCE)1084-0699(2005)10:3(237)

European Commission 2000. Directive 2000/60/EEC. Establishing a framework for community action in the field of water policy. Luxembourg, Official Journal of the European Communities, L327. 1-71.

European Commission 2006. Ecoflood guidelines: How to use floodplains for flood risk reduction. Report EUR 22001. Luxembourg, Office for Official Publications of the European Communities.

European Commission 2007. Directive 2007/60/EC of the European Parliament and of the Council on the assessment and management of flood risks. Official Journal of the European Union L 288. 27-34.

European Commission 2014. A guide to support the selection, design and implementation of Natural Water Retention Measures in Europe: Capturing the multiple benefits of nature-based solutions. Brussels, European Commission. Available at http://www.ecrr.org/ Portals/27/Publications/NWRMpublication.pdf

European Union 2014. EU policy document on Natural Water Retention Measures. Technical report 2014-082. file://C:/Users/Dell/Downloads/olicyDocumentonNaturalWaterRetentionMeasures_Final.pdf

Fábián, Sz.Á., Kovács, J., Lóczy, D., Schweitzer, F., VARGA, G., BABÁK, K., LAMPÉRT, K. and NAGY, A. 2006. Geomorphologic hazards in the Carpathian Foreland, Tolna County (Hungary). Studia Geomorphologica Carpatho-Balcanica 11. 107-118. 
Ferk, M., Ciglič, R., Komac, B. and Lóczy, D. 2020. Management of small retention ponds and their impact on flood hazard prevention in the Slovenske Gorice Hills. Acta geographica Slovenica 60. 107-125. Doi: https://doi.org/10.3986/AGS.7675

Fiener, P. and Auerswald, K. 2003. Effectiveness of grassed waterways in reducing run-off and sediment delivery from agricultural watersheds. Journal of Environmental Quality 32. (3): 927-936. Doi: $10.2134 /$ jeq2003.0927

Fisher, B. and TURNER, K. 2008. Ecosystem services: Classification for valuation. Biological Conservation 141. 1167-1169.

Fuentes, J.P. 2003. Influence of tillage on soil properties under agricultural and natural prairie systems. Doctorate dissertation. Tacoma, WA, USA, Washington State University. Available at http:// hdl.handle.net/2376/152

Gotoh, H., Maeno, Y., Takezawa, M. and Ohnishi, M. 2011. Flood control and small-scale reservoirs. In River Basin Management VI. Ed.: BRebBia, C.A., Southampton, UK, WIT Press, 51-60. Doi: 10.2495/ RM110051

Grobicki, A., MacLeod, F. and PischKe, F. 2015. Integrated policies and practices for flood and drought risk management. Water Policy 17. (1): 180-194. Doi: 10.2166/wp.2015.009

Guerrero, B., Amosson, S., Nair, S. and Marek, T. 2017. The importance of regional analysis in evaluating agricultural water conservation strategies. Journal of Regional Analysis and Policy 47. (2): 188-198. Doi: 10.22004/ag.econ.293632

Haber, W. 2014. Landwirtschaft und Naturschutz. Weinheim, Germany, Wiley-VCH Verlag.

Haines-Young, R. and Potschin, M. 2011. Common International Classification of Ecosystem Services (CICES): 2011 Update. London, European Environment Agency. Available at https://cices.eu/ content/uploads/sites/8/2009/11/CICES_Update_ Nov2011.pdf

Hinman, C. 2005. Low Impact Development Technical Guidance Manual for Puget Sound. Tacoma, WA, USA, Washington State University.

Hjerdt, K.N., McDonnell, J.J., Seibert, J. and Rodhe, A. 2004. A new topographic index to quantify downslope controls on local drainage. Water Resources Research 40. W05602. Doi:10.1029/2004WR003130.

Horoszné Gulyás, M. 2012. Lefolyás-szabályozás és talajvédelem (Run-off regulation and soil conservation). Természetföldrajzi Közlemények a Pécsi Tudományegyetem Földrajzi Intézetéból 1. (2): 41-56. (in Hungarian)

Hümann, M., Müller, C., Schüler, G., Schneider, R. and Thiele-Bruhn, S. 2011. Identification of run-off generation processes - Impact of different forest types on soil-water interrelations. Geophysical Research Abstracts 13. EGU2011-8035-1
IPCC 2013. Climate Change 2013: The Physical Science Basis. Summary for Policymakers. Intergovernmental Panel of Climate Change. Cambridge, UK, Cambridge University Press, Available at https://www. ipcc.ch/site/assets/uploads/2018/03/WG1AR5_ SummaryVolume_FINAL.pdf

IUCN 1997. Fishing for a Living: The Ecology and Economics of Fishponds in Central Europe. Cambridge, UK, International Union for Nature Conservation Publication.

Jørgensen, D. and Jørgensen, F.A. 2018. Aesthetics of energy landscapes. Environment, Space, Place 10. (1): 1-14. Doi: 10.5749/envispacplac.10.1.0001

Juhos, K., CZigánY, Sz., Madarász, B. and LadánYi, M. 2019. Interpretation of soil quality indicators for land suitability assessment - a multivariate approach for Central European arable soils. Ecological Indicators 99. 261-272. Doi: 10.1016/j.ecolind.2018.11.063

Kertész, Á., Madarász, B., Csepinszky, B. and Benke S. 2010. The role of conservation agriculture in landscape protection. Hungarian Geographical Bulletin 59. (2): 167-180.

Kocsis, T. and ANDA, A. 2006. Microclimate simulation of climate change impacts in a maize canopy. Idojórás 116. (2): 109-122.

KорескÝ, M. and ČížKovÁ, S. 2010. Using topographic wetness index in vegetation ecology: does the algorithm matter? Applied Vegetation Science 13. 450-459. Doi: 10.1111/j.1654-109X.2010.01083.x

KSH 2012. Mezógazdaság, 2011 (Agriculture, 2011). Budapest, Central Statistical Office (KSH). Availabe at https://www.ksh.hu/docs/hun/xftp/idoszaki/ mezo/mezo11.pdf

Kundzewicz, Z.W., Hegger, D.L.T., Matczak, P. and Driessen, P.P.J. 2018. Flood-risk reduction: Structural measures and diverse strategies. PNAS 115. (49): 12321-12325. Doi: 10.1073/pnas.1818227115

Laterra, P., Orúe, M.E. and Booman, G.C. 2012. Spatial complexity and ecosystem services in rural landscapes. Agriculture, Ecosystems and Environment 154. 56-67. Doi: 10.1016/j.agee.2011.05.013

Leitinger, G., Tasser, E., Newesely, C., Овojes, N. and TAPPEINERET, U. 2010. Seasonal dynamics of surface run-off in mountain grassland ecosystems differing in land use. Journal of Hydrology 385. (1-4): 95-104.

Lóczy, D. 1998. Man-made terraces in a German agricultural landscape. Supplementi di Geografia Fisica e Dinamica Quaternaria 21. (1): 55-59.

Lóczy, D., Czigány, Sz. and Pirkhoffer, E. 2012. Flash flood hazards. In Studies on Water Management Issues. Ed.: Kumarasamy, M., Rijeka, InTech, 27-52. Doi: $10.5772 / 28775$.

Lóczy, D. 2013. Hydromorphological-geoecological foundations of floodplain management: Case study from Hungary. Saarbrücken, Lambert Academic Publishing.

Moore, M.T., Bennett, E.R., Farris, J.L. and Douglas SHIELDS, F. JR. 2004. Innovative uses of vegetated 
drainage ditches for reducing agricultural run-off. Water Science \& Technology 49. (3): 117-123. Doi: 10.2166/wst.2004.0176

Murphy, P.N.C., Ogilvie, J. and Arp, P. 2009. Topographic modelling of soil moisture conditions: a comparison and verification of two models. European Journal of Soil Science 60. 94-109. Doi: 10.1111/j.1365-2389.2008.01094.x

Niv, C.Y., Musa, A. and Liv, Y. 2015. Analysis of soil moisture condition in arid region of northern China. Solid Earth 6. 1157-1167. Doi: 10.5194/se-61157-2015

Otto, S., Pappalardo, S.E., Cardinali, A., Masin, R., Zanin, G. and Borin, M. 2016. Vegetated ditches for the mitigation of pesticides run-off in the Po Valley. PLoS ONE 11. (4): e0153287. Doi: 10.1371/ journal.pone. 0153287

Peng, S.H. and Han, K.T. 2018. Assessment of aesthetic quality on soil and water conservation engineering using the scenic beauty estimation method. Water 10. 407-422. Doi: 10.3390/w10040407

Pourali, S., Arrowsmith, C., Chrisman, N., Matkan, A.A. and MrtcheLL, D. 2016. Topography Wetness Index application in flood-risk-based land use planning. Applied Spatial Analysis 9. 39-54. Doi: 10.1007/s12061-014-9130-2

Pyke, C., Warren, M.P., Johnson, T., LaGro, J. Jr., Scharfenberg, J., Groth, P., Freed, R., Schroeer, W. and Marn, E. 2011. Assessment of low impact development for managing storm water with changing precipitation due to climate change. Landscape and Urban Planning 103. 166-173. Doi: 10.1016/j.landurbplan.2011.07.006

Qiu, Z., Pennock, A., Giri, S., Trnka, C., Du, X. and WANG, H. 2017. Assessing soil moisture patterns using a soil topographic index in a humid region. Water Resources Management 31. (7): 2243-2255. Doi:10.1007/s11269-017-1640-7

Radula, M.W., Szymura, T.H. and Szymura, M. 2018. Topographic wetness index explains soil moisture better than bioindication with Ellenberg's indicator values. Ecological Indicators 85. 172-179. Doi:10.1016/j.ecolind.2017.10.011

Ribeiro, D. and Šmid Hribar, M. 2019. Assessment of land-use changes and their impacts on ecosystem services in two Slovenian rural landscapes. Acta geographica Slovenica 59. (2): 143-160. Doi: 10.3986/ AGS.6636

Scholz, M. 2003. Sustainable operation of a small-scale flood-attenuation wetland and dry pond system. Water and Environment Journal 17. 171-175. Doi: 10.1111/j.1747-6593.2003.tb00457.x

SHARMA, A. 2010. Integrating terrain and vegetation indices for identifying potential soil erosion risk area. Geo-spatial Information Science 13. 201-209. Doi:10.1007/s11806-010-0342-6

SeEgER, M. and Ries, J.B. 2008. Soil degradation and soil surface process intensities on abandoned fields in Mediterranean mountain environments. Land Degradation and Development 19. (5): 488-501. Doi: 10.1002/ldr.854

Šmid Hribar, M., Geršič, M., Pipan, P., Repolusk, P., Tiran, J., Topole, M. and Ciglič, R. 2017. Cultivated terraces in Slovenian landscapes. Acta geographica Slovenica 57. (2): 83-97. Doi: 10.3986/AGS.4597

Sørensen, R., Zinko, U. and Seibert, J. 2005. On the calculation of the topographic wetness index: evaluation of different methods based on field observations. Hydrology and Earth System Sciences Discussions, European Geosciences Union 2. (4): 1807-1834.

SтоLте, J. 2003. Effects of land use and infiltration behaviour on soil conservation strategies. Doctoral Thesis. Wageningen, Wageningen University. Available at https://edepot.wur.nl/121446

Stürck, J., Poortinga, A. and Verburg, P.H. 2014. Mapping ecosystem services: The supply and demand of flood regulation services in Europe. Ecological Indicators 38. 198-211. Doi: 10.1016/j. ecolind.2013.11.010

Syrbe, R.-U. and Grunewald, K. 2013. Restrukturierungsbedarf für regionaltypische Landschaftselemente und Biotopstrukturen am Beispiel Sachsens. Natur und Landschaft 88. (3): 103-111.

Tanács, E., Belényesi, M., Lehoczki, R., Pataki, R., Petrik, O., Standovár, T., Pásztor, L., Laborczi, A., Szatmári, G., Molnár, Zs., Bede-Fazekas, Á., Kisné Fodor, L., VARGA, I., Zsembery, Z. and MaUcha, G. 2019. Országos, nagyfelbontású ökoszisztémaalaptérkép: módszertan, validáció és felhasználási lehetőségek (National large-scale ecosystem base map: methodology, validation and utilization opportunities). Természetvédelmi Közlemények 25.34-58. Doi: 10.17779/tvk-jnatconserv.2019.25.34

TEEB 2010. Chapter 5. The economics of valuing ecosystem services and biodiversity. In The Economics of Ecosystems and Biodiversity: Ecological and Economic Foundations. Ed.: Kumar, P., Cambridge, Earthscan Publications, 1-133.

Thiem, K. and Bastian, O. 2014. Steckbriefe für ausgewählte landschaftsprägende historische Kulturlandschaftselementtypen im Freistaat Sachsen. Historische Kulturlandschafts-elemente Sachsens 18/2014 Dresden, Sächsisches Landesamt für Umwelt, Landwirtschaft und Geologie (LfULG). Available at https://publikationen.sachsen.de/bdb/

Thomas I.A., Jordan P., Shine O., Fenton O., Mellander P.-E., Dunlop P. and Murphy P.N.C. 2017. Defining optimal DEM resolutions and point densities for modelling hydrologically sensitive areas in agricultural catchments dominated by microtopography. International Journal of Applied Earth Observation and Geoinformation 54. 38-52.

Tölgyesi, C., Töröк, P., Hábenczyus, A.A., BÁtori, Z., Valkó, O., Deák, B. and Kelemen, A. 2020. Underground deserts below fertility islands? 
Woody species desiccate lower soil layers in sandy drylands. Ecography 43. (6): 848-859. Doi: 10.1111/ ecog.04906

Vandecastaele, I., Marí i Rivero, I. Baranzelli, C., Becker, W., Dreoni, I. Lavalle, C. and Batelaan, O. 2018. The Water Retention Index: Using land use planning to manage water resources in Europe. Sustainable Development 26. 122-131. Doi: 10.1002/ sd.1723

VÝletA, R., DANÁČová, M., ŠKRINÁR, A. FENCík, R. and Hlavčová, K. 2017. Monitoring and assessment of water retention measures in agricultural land. Earth and Environmental Science 95. 022008. Doi: 10.1088/1755-1315/95/2/022008

WANG, H., GAO, J.E., Zhang, S.L., Zhang, M.J. and Li, X.H. 2013. Modeling the impact of soil and water conservation on surface and ground water based on the SCS and Visual MODFLOW. PLoS One 8. (11): e79103. Doi: 10.1371/journal.pone.0079103

Wang, S., Fu, B., GaO, G., Liu, Y. and Zhou, J. 2013. Responses of soil moisture in different land cover types to rainfall events in a re-vegetation catchment area of the Loess Plateau, China. CATENA 101. 122-128. Doi: 10.1016/j.catena.2012.10.006

Wei, W., Chen, D., Wang, L.X., Daryanto, S., Chen, L.D., YU, Y., Sun, G. and FEnG, T.J. 2016. Global synthesis of the classifications, distributions, benefits and issues of terracing. Earth-Science Reviews 159. Doi: 10.1016/j.earscirev.2016.06.010
World Bank 2019. Assessing Drought Hazard and Risk: Principles and Implementation Guidance. Washington, D.C., World Bank. Available at https://reliefweb.int/sites/reliefweb.int/files/ resources/\%E2\%80\%A2Drought_FINALWEB_ LOWHRES.pdf

ZHou, Q.M. 2017. Digital Elevation Model and Digital Surface Model. In The International Encyclopedia of Geography. Ed.-in-Chief. Richardson, D., New York, American Association of Geographers - John Wiley and Sons. Doi: 10.1002/9781118786352.wbieg0768

Zorn, M. and Комас, B. 2011. The importance of measuring erosion processes on the example of Slovenia. Hrvatski Geografski Glasnik 73. (2): 19-34.

Zucco, G., Brocca, L., Moramarco, T. and Morbidelli, R. 2014. Influence of land use on soil moisture spatial-temporal variability and monitoring. Journal of Hydrology 516. 193-199. Doi: 10.1016/j. jhydrol.2014.01.043

ŽvoKelJ, B.P., Bric, V. and Triglav ČEKadA, M. 2015. Lasersko skeniranje in aerofotografiranje Slovenije. Geodetski vestnik 58. (2): 349-351. 